\title{
MEDIATION IN ECONOMIC DISPUTES
}

\author{
Elżbieta PAWŁOWSKA ${ }^{1 *}$, Johanna WRANIK ${ }^{2}$ \\ ${ }^{1}$ Silesian University of Technology, Faculty of Organization and Management, Department of Management and \\ Logistics, Zabrze; epawlowska@polsl.pl, ORCID: 0000-0001-6863-5430 \\ ${ }^{2}$ Silesian University of Technology, Faculty of Organization and Management, Department of Management and \\ Logistics, Zabrze; johanna.wranik805@gmail.com, ORCID: 0000-0002-8937-0686 \\ * Correspondence author
}

Purpose: The purpose of the article is to present the use of the mediation tool in resolving economic disputes on the example of the Silesian Voivodeship.

Design/methodology/approach: The comparative analysis methodology was selected for the purposes of this study. Analysis as a technique for recognizing the types of elements forming a given whole on the basis of their characteristics and assessing the efficiency of the whole functioning against the background of the adopted pattern. The analysis was conducted in two selected regional courts in the Silesian Voivodeship.

Findings: Currently, an increasing number of commercial cases pending before the courts can be observed, however, the institution of mediation still plays a negligible role in their resolution. Mediation focuses on the future of the parties, avoids escalation of the problem and is a highly individualized process. An undoubted problem regarding mediation is the lack of trust of both courts and the public in this form of resolving the conflict. Currently, mediation is not sufficiently used, which is why education and promotion are so important in this regard.

Originality/value: The presented analysis is important because it indicates the role of mediation and the essence of its popularization in overcoming society's reluctance. To achieve this, it is necessary to promote information on mediation, train judges in effective urging the parties to mediate, and make young people aware of the many benefits of settling everyday problems.

Keywords: economic disputes, conflict, agreement.

Category of the paper: research paper.

\section{Introduction}

Mediation is a phenomenon that was disseminated in the 1970s. According to the Directive of the European Parliament and of the Council, mediation means an organised, voluntary process, however named or referred to, in which two or more parties to a dispute attempt to reach an agreement on their dispute with the assistance of a mediator. Such proceedings may 
be initiated by the parties, or may be proposed or ordered by a court or ordered by the law of a Member State.

Mediation may concern various types of matters, including family, criminal, administrative, labour law, civil matters as well as economic matters. The latter are particularly important because they are associated with commonly occurring social or economic phenomena. It is important to move away from the stereotypical approach, which consists in referring the case to court and directing mediation proceedings, which brings many positive effects.

The main advantage of mediation is the efficiency and durability of solutions developed by the parties on their own. "Research indicates that statistics on mediation agreements range between $50-80 \%$, with a tendency towards a higher rather than a lower frequency" (Gójska, 2007). The settlements formally approved at the last stage of mediation also satisfy applicants because they include the needs of each party and are based on their internal understanding of justice.

The sense of dignity and a decent solution to the case is preserved, because it is the participants of mediation that have decision-making power. Through the fundamental role of the parties, and only the supporting role of a mediator, mediation increases the sense of value and competence among those in conflict. Mediation emphasizes open and decent conversations that take place in relation to earlier, jointly established rules. Thanks to this, the result generated during mediation is highly individualized and does not have to coincide with the solutions proposed by law or courts. It is also unique in mediation that participants can change its purpose at any time and the door to reconciliation will always be open. With the help of communication and appropriate engagement of the parties, there is a chance to reduce or completely eliminate the hostility and tension between the parties. This is important if the parties must maintain a relationship in the future. An important advantage of mediation is also its focus on the future. The goal is to find a solution that is acceptable to both parties, not to indicate the guilty, which means that after the mediation the parties remain on good terms. So this is a process of joint success, unlike the court, which decides to win only one of the parties. Informal, lack of organizational restrictions, flexibility and a private, peaceful atmosphere make mediation more attractive than a lawsuit. It can be used in a variety of situations, at various stages of the dispute, with a large number of parties and varying degrees of complexity. For society, however, the most important advantage of mediation is speed and lower costs. Arbitration avoids stress and negative emotions associated with court proceedings and limits the influence of public institutions in the private life of the individual.

The Ministry of Economy has estimated that conflicts in economic matters in Poland generate annually about PLN 40 billion in costs for entrepreneurs. These are costs associated with hiring a lawyer, court fees, as well as losses related to loss of trust and reputation among clients (Pieckowski, 2015). It is therefore important to move away from the stereotypical approach which is to take the case to court, and focus on mediation proceedings, which brings 
many positive effects. That is why it is interesting to present the use of the mediation tool in resolving economic disputes on the example of the Silesian Voivodeship.

\section{Literature review}

At present, mediation plays an important role in resolving all kinds of conflicts, including economic disputes. Mediation enables to reach a compromise quickly and efficiently with relatively low expenditure incurred for this purpose. Mediation (Latin mediare - to mediate a dispute; medius - middle, impartial; mediator - indirect) (Kopaliński, 2000). The institution of mediation as a tool to resolve conflicts between the parties, has a strong relationship with the principle of social justice, among other things, contained in the Constitution. This principle is a component of the legal order and political system of the state, in which every citizen has the same criteria for assessing rights and obligations, or even merit and guilt. On the other hand, state authorities are required to have impartiality in their functioning (https://encyklopedia.pwn.pl, 2020).

In literature this term covers mediation conducted by a judge who is not responsible for any judicial proceedings concerning the dispute in question. However, it shall not include attempts made by the court or judge seized to settle the dispute in the course of judicial proceedings concerning the dispute in question (Directive 2008/52/EC of the European Parliament and of the Council of 21 May 2008). Modern mediation is understood in the Act as a facilitative process in which the parties discuss their dispute with an impartial person who assists them to reach a resolution. Although it is a process based on party consent, the court can also refer parties to mediation. If the parties reach a settlement in mediation, their agreement has the same status as an arbitral award (Nolan-Haley, Kwasi Annor-Ohene, 2014). Mediation is an intermediary in the dispute for facilitation of its participants participating in obtaining a consensus. It helps in determining the severity of the conflict, it also aims to increase the reach for mutual concessions or finally justify the relationship. During mediation, the past is relevant only in compilations to the present as a basis for predicting the future in terms of needs, abilities and response to decisions (Folberg, Taylor, 1984). According to M. Tabernecka, mediation is a process that serves to reach an agreement, both in case of a dispute and in a situation of deadlock and stagnation in negotiations. Mediation can also serve to establish contact between the parties (Tabernacka, 2018). A similar definition is presented by D. Peters, defining it as assisted negotiations, and negotiations are the most common procedure in building legal relations and resolving disputes (Peters, 2015). In turn, according to P. Soltysiak, mediation is a peaceful process in which a third party tries to bring the positions of the parties closer together, to ease the existing tensions between them and to create conditions for finding a solution acceptable to everyone (http://dlibra.bg.ajd.czest.pl, 2018). 
Mediation is a process whereby the parties agree to instruct a neutral person, who is independent from them, to assist them in trying to solve an issue that is dividing them. It is a voluntarily process, whereby they are encouraged to listen to one another confidentially without an obligation to continue if they do not want to continue. Unless there are other arrangements, they have to have the power to make binding agreements. Mediation helps to bridge differences by helping parties to recognise that their take on 'reality' is just that a paradigm and not an objective assessment of what 'just is' (Gilovich, Ross, 2016). A. Doyle (Doyle, 2016) recommended various measures to this end including: analyse and understand (potential) sources of conflict, empower people to become more conflict competent, constructively promote and influence ethical behaviour, support risk management and risk mitigation, and provide a general narrative that can bring insight to information. At the level of large corporations and even relatively small business interests, mediation is increasingly used as a private alternative to expensive litigation. Speed, cost, and confidentiality - the importance of which is not to be underestimated - are attractive to parties especially where legal precedent is not an issue (Lipsky, Seeber, Hall, 2004), A. Kalisz and A. Zienkiewicz defined mediation as a form of dispute resolution based on specialized, non-manipulative interference of a third party, impartial and neutral towards the parties and their conflict. The authors, in addition to identifying the person of the mediator, as an entity that remains objective during the mediation procedure, also specified its tasks. These include, among others, bringing the parties to the dispute to an agreement that is mutually acceptable and takes into account the interests and needs of both parties. In addition, it is also important to rebuild positive relations and attitudes of cooperation between the parties to the dispute, as well as to bring them to self-knowledge and self-improvement (Kalisz, Zienkiewicz, 2014). The mediator cannot suggest to the parties how to resolve the dispute, and the mediation proceedings should be conducted in such a way that the conflicting individuals individually come to an agreement that must be structured to include a solution to all elements of the conflict in a manner acceptable to the parties to the conflict, satisfying both parties. In addition, the mediator should strive to repair the relationships of conflicting entities so that there are no further conflicts in the future.

The following features of mediation are indicated in the legal doctrine:

- the will of the parties to resolve the dispute by means of an agreement reached,

- equality of parties to the dispute involved in mediation,

- the possibility for conflicting parties to submit arguments and allegations,

- orientation towards achieving such a solution that will be accepted by all parties to mediation,

- mediation by a neutral mediator who, as an entity not involved in the conflict, will help the parties reach a consensus,

- not imposing any solution to the matter in which mediation is conducted,

- a court guarantee of enforceability of the agreement reached as a result of mediation (Moll, 2015). 
Mediation is initiated ex officio or at the request of at least one of the parties to the conflict, however, in order for it to be possible, a declaration of will of the parties involved is required. Mediation is a flexible process. The flexibility of mediation is the opportunity to start them at any convenient time. Mediations should take place taking into account certain principles set out in the Council of Europe Recommendations. These principles apply to each stage of mediation and are: the principle of voluntariness, confidentiality, the principle of impartiality, the principle of neutrality and the principle of acceptability. These rules are mandatory (Rękas, 2011).

In accordance with art. 2 clause 1 of the Act on the recognition of economic cases by the courts, commercial cases are cases related to civil relations between entrepreneurs in the scope of their business activity (Journal of Laws, 2016, item 723). The legislator assumes that any conflict of interests arising between entrepreneurs regarding their activities qualifies for business case. In addition, in art. 2 clause 2, the above Act expands the scope of business matters by adding: matters related to the company's relationship and claims (The Act of 15 September 2000), cases against entrepreneurs for non-violation of the environment, cases between the bodies of a state-owned enterprise, cases between a state-owned enterprise or its organs and its founding or supervisory body, cases in the field of bankruptcy and restructuring law, and others.

As mentioned, the subjects of economic mediation are entrepreneurs involved in the conflict, i.e. natural or legal persons conducting business activity. The parties come to mediation in order to maintain the good reputation of the company, stay in positive business relations and, above all, quickly enforce an effective solution with relatively low outlays incurred for this purpose in comparison with bringing a case to court. It can therefore be concluded that mediation allows entrepreneurs to save time, reduce costs and maintain good relations between themselves. The table below presents the differences between court proceedings and mediation.

\section{Table 1.}

Features of court proceedings and mediation proceedings

\begin{tabular}{|l|l|}
\hline Court proceedings & Mediation proceedings \\
\hline Chronicity of proceedings & Speed of proceedings \\
\hline High court costs & Low costs \\
\hline Publicity of the proceedings & Confidentiality of proceedings \\
\hline $\begin{array}{l}\text { Inflammation of the relationship between } \\
\text { entrepreneurs }\end{array}$ & Improving relationships between entrepreneurs \\
\hline $\begin{array}{l}\text { Settlement of the dispute by the court - lack of } \\
\text { control over the outcome of the proceedings, limited } \\
\text { influence of the parties }\end{array}$ & Joint development of solutions satisfying both sides \\
\hline No choice of judge & Freedom in choosing a mediator \\
\hline $\begin{array}{l}\text { Strong time limit for the parties' statements at court } \\
\text { meetings }\end{array}$ & The mediation time is agreed by the parties, together \\
\hline
\end{tabular}

Source: Binsztok A.: Economic Mediation. Publishing Marina, Wrocław 2015, s. 16.

The differences above are presented to highlight the benefits of choosing an alternative form of dispute resolution, which is mediation instead of court proceedings. Mediation proceedings compared to court proceedings are distinguished by their shortened duration of proceedings. 
This difference is huge, as court cases can last for years, while a mediation dispute can be resolved even during one mediation meeting. The length of proceedings is closely related to their costs, the longer the proceedings, the greater the expenses, additionally court fees apply in courts. The institutions of justice are subject to the principle of openness of proceedings, while out-of-court proceedings the principle of confidentiality applies. The courtroom rather contributes to the aggravation of relations between the parties, usually one side wins and the other loses. However, during mediation, long talks and negotiations can be conducted during which each party determines what they want, which they can opt out of, and the culmination is a compromise that satisfies both parties. In addition, in judicial proceedings it is not possible to choose a judge, while the alternative conflict resolution method allows the parties to independently choose a mediator who has the appropriate competence. It can therefore be concluded that out-of-court mediation is an interesting alternative to court proceedings.

It can therefore be concluded that the initiation of mediation proceedings avoids the negative effects incurred by the entrepreneur, and ending it with a settlement may contribute to a positive reception of the company.

\section{Economic mediation in Poland}

In Poland, the number of cases referred to mediation in the field of economic matters is still small, but their upward trend can be observed. Economic matters may be heard by both district and county courts. Their qualification depends on the value of the subject of dispute. Cases under the amount of PLN 75 thousand in dispute value are directed to district courts, while if the value is equal to or higher, the matter is taken over by the appropriate regional court. The table below presents the number of cases referred by the district courts to mediation in Poland.

\section{Table 2.}

Mediation proceedings in commercial cases in district courts in the years 2013-2017 in Poland

\begin{tabular}{|c|c|c|c|c|c|c|}
\hline \multicolumn{2}{|c|}{ Mediation proceedings } & $\mathbf{2 0 1 3}$ & $\mathbf{2 0 1 4}$ & $\mathbf{2 0 1 5}$ & $\mathbf{2 0 1 6}$ & $\mathbf{2 0 1 7}$ \\
\hline \multirow{2}{*}{$\begin{array}{c}\text { Number of cases referred to mediation by a court (art. } \\
183^{8} \S 1 \text { Code of Civil Procedure) }\end{array}$} & 1656 & 1834 & 4138 & 4210 & 3542 \\
\cline { 2 - 6 } & $\begin{array}{c}\text { Number of protocols submitted by mediators (art. } \\
183^{13} \S 2 \text { Code of Civil Procedure) }\end{array}$ & 492 & 586 & 1105 & 1010 & 968 \\
\cline { 2 - 6 } & $\begin{array}{c}\text { The proceedings were discontinued as a result of } \\
\text { approval of the mediation settlement (art. } 183^{14} \S 1 \text { i } 2 \\
\text { Code of Civil Procedure) }\end{array}$ & 340 & 296 & 338 & 452 & 530 \\
\cline { 2 - 6 } & $\begin{array}{c}\text { The settlement was refused pursuant to art. 183 }{ }^{14} \S 3 \\
\text { Code of Civil Procedure }\end{array}$ & 40 & 8 & 15 & 65 & 9 \\
\hline
\end{tabular}


Cont. table 2.

\begin{tabular}{|c|c|c|c|c|c|c|}
\hline \multirow{4}{*}{ 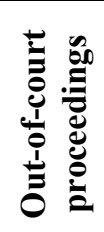 } & $\begin{array}{l}\text { Number of protocols submitted by mediators (art. } \\
183^{13} \S 1 \text { Code of Civil Procedure) }\end{array}$ & 53 & 52 & 13 & 17 & 116 \\
\hline & Number of requests for settlement approval & 44 & 57 & 9 & 7 & 25 \\
\hline & The settlement was approved - total & 92 & 107 & 14 & 13 & 30 \\
\hline & $\begin{array}{l}\text { The settlement was refused pursuant to art. } 183^{14} \S 3 \\
\text { Code of Civil Procedure }\end{array}$ & - & 2 & - & - & 1 \\
\hline
\end{tabular}

Source: Mediation proceedings in the light of statistical data, district and district courts in the years 2006-2016 and the first half of 2017, 4th Edition”, Department of Statistical Management Information Department of Strategy and European Funds Ministry of Justice. Warsaw 2017, page 9./Data of the Ministry of Justice.

The above data shows that every year the courts refer an increasing number of cases to mediation. In 2013, there were 1656 cases, while in 2017 the number of these cases doubled. Of all cases referred to mediation by the court in 2017 , only about $15 \%$ were completed by a settlement and confirmed by court. In extrajudicial proceedings, the number of cases on which the condition of enforceability has been imposed has, unfortunately, a downward trend. Number of approved settlements in 2017 compared to 2013, fell by as much as $30 \%$. The reason for this situation may be the fact that the number of entrepreneurs who directly go to the mediator to reach a settlement has decreased. The table below presents the number of commercial cases referred to mediation by regional courts in 2013-2017 in Poland.

Table 3.

Mediation proceedings in commercial matters in regional courts in 2013-2017 in Poland

\begin{tabular}{|c|c|c|c|c|c|c|}
\hline \multicolumn{2}{|r|}{ Mediation proceedings } & 2013 & 2014 & 2015 & 2016 & 2017 \\
\hline \multirow{4}{*}{ 递 } & $\begin{array}{l}\text { Number of cases referred to mediation by a court (art. } \\
183^{8} \S 1 \text { Code of Civil Procedure) }\end{array}$ & 1156 & 1262 & 1606 & 2034 & 1960 \\
\hline & $\begin{array}{l}\text { Number of protocols submitted by mediators (art. } 183^{13} \\
\S 2 \text { Code of Civil Procedure) }\end{array}$ & 514 & 527 & 796 & 855 & 891 \\
\hline & $\begin{array}{l}\text { The proceedings were discontinued as a result of } \\
\text { approval of the mediation settlement (art. } 183^{14} \S 1 \text { i } 2 \\
\text { Code of Civil Procedure) }\end{array}$ & 195 & 251 & 302 & 383 & 466 \\
\hline & $\begin{array}{c}\text { The settlement was refused pursuant to art. } 183^{14} \S 3 \\
\text { Code of Civil Procedure }\end{array}$ & 36 & 2 & 64 & 12 & 6 \\
\hline \multirow{4}{*}{ 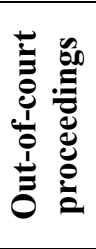 } & $\begin{array}{l}\text { Number of protocols submitted by mediators (art. } 183^{13} \\
\S 1 \text { Code of Civil Procedure) }\end{array}$ & 6 & 6 & 10 & 13 & 12 \\
\hline & Number of requests for settlement approval & 6 & 5 & 10 & 13 & 11 \\
\hline & The settlement was approved - total & 10 & 9 & 15 & 13 & 12 \\
\hline & $\begin{array}{l}\text { The settlement was refused pursuant to art. } 183^{14} \S 3 \\
\text { Code of Civil Procedure }\end{array}$ & - & - & 3 & - & - \\
\hline
\end{tabular}

Source: Mediation proceedings in the light of statistical data, district and district courts in the years 2006-2016 and the first half of 2017, 4th Edition", Department of Statistical Management Information Department of Strategy and European Funds Ministry of Justice. Warsaw 2017, page 23./Data of the Ministry of Justice.

Based on the above table, it can be observed that until 2016 there was an upward trend in referring cases to mediation by courts, while in 2017 there was a slight decrease. In only $25 \%$ of cases referred to mediation by courts in 2017 the proceedings were discontinued as a result of approval of a mediation settlement. In turn, in out-of-court mediation proceedings, the courts approved all complex settlements. Based on the above table, it can be concluded that the number of out-of-court mediation proceedings is very small. The reason for this may be the fact that 
entrepreneurs are not aware of the mediation institution, as well as their fear of the high value of the subject of the dispute to be mediated.

Making a detailed description of cases referred to mediation in the Śląskie Voivodeship, it can be stated that this number is still small. The results are presented in the table below.

Table 4.

The number of economic cases referred to mediation by district courts in the Silesian Voivodeship in 2018

\begin{tabular}{|c|c|}
\hline District & District courts \\
\hline Bielsko district & 43 \\
\hline Częstochowa district & 0 \\
\hline Gliwice district & 39 \\
\hline Katowice district & 111 \\
\hline
\end{tabular}

Source: own study based on data from the Ministry of Justice: postepowanie-mediacyjne-w-sr-i-so-wlatach-2006-2018-i-ip.2019-2019.10.23.pdf, as of 17.12.2019.

The Silesian Voivodeship achieves very low results in referring economic cases to mediation. In 2018 the largest number of cases for mediation was transferred in the Katowice district, while in the Bielsko and Gliwice districts about $60 \%$ less cases were transferred to mediation, and in the Częstochowa district the district court did not refer any matter to mediation (there is no economic department). Comparing the above data to the Warsaw district (809 cases) or Wrocław district (240 cases) (Mediation proceedings in the light of statistical data district and district courts in the years 2006-2018 and in the first half of 2019), it can be safely stated that the number of cases referred to mediation in the Śląskie Voivodeship is very low. This situation may be related to the fact that few judges believe in the effectiveness of mediation as an amicable form of dispute resolution, or whether entrepreneurs are not oriented towards conflict resolution using the mediation formula.

\section{Economic mediation in selected regional courts in the Silesian Voivodeship - comparative analysis}

The comparative analysis methodology was selected for the purposes of this study. J. Penc defines comparative analysis as a technique for recognizing the types of elements forming a given whole on the basis of their characteristics and assessing the efficiency of the whole functioning against the background of the adopted pattern (Penc, 1977). The analysis was conducted in two selected regional courts in the Silesian Voivodeship. Every year, the first analyzed regional court receives approximately two thousand new economic cases. The figure below shows the number of commercial cases pending before the regional court in 2010-2017. 


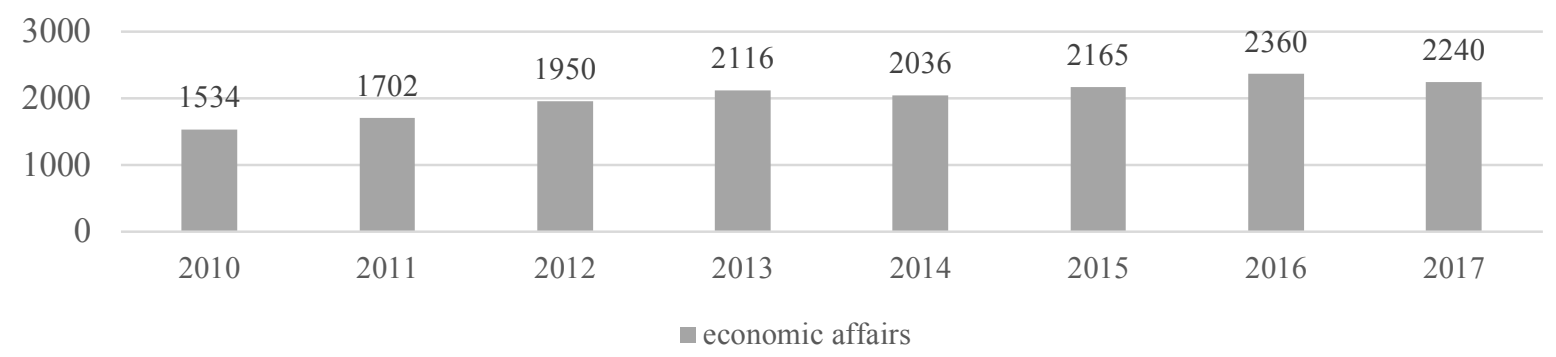

Figure 1. The inflow of economic cases to the regional court in 2010-2017. Source: own study based on data from the Regional Court of the Silesian Voivodeship.

The number of cases received by the economic department from 2010 to 2017 increased by about 30\%. In 2014 and 2017 there was a slight decrease in their impact compared to other years. Most cases went to court in 2016, it was 2,360 lawsuits. Unfortunately, only a small part of them was referred to mediation. The table below presents the number of cases referred to mediation by the abovementioned court.

Table 5.

Mediation proceedings in economic matters in the analyzed Regional Court in 2010-2017

\begin{tabular}{|c|c|c|c|c|c|c|c|c|c|}
\hline \multicolumn{2}{|r|}{ Mediation matters } & 2010 & 2011 & 2012 & 2013 & 2014 & 2015 & 2016 & 2017 \\
\hline \multirow{5}{*}{ 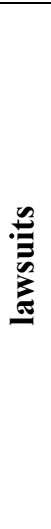 } & $\begin{array}{l}\text { Number of cases referred to } \\
\text { mediation by a court (art. } 183^{8} \\
\S 1 \text { Code of Civil Procedure) }\end{array}$ & 9 & 3 & 10 & 6 & 7 & 7 & 69 & 49 \\
\hline & $\begin{array}{c}\text { Number of protocols submitted } \\
\text { by mediators (art. } 183^{13} \S 2 \text { Code } \\
\text { of Civil Procedure) }\end{array}$ & 10 & 4 & 6 & 5 & 3 & 7 & 30 & 28 \\
\hline & impact together & 19 & 7 & 16 & 11 & 10 & 14 & 99 & 77 \\
\hline & $\begin{array}{l}\text { approval of the settlement } \\
\text { before the mediator (art. } 183^{14} \\
\S 1 \text { i } 2 \text { Code of Civil Procedure) }\end{array}$ & 4 & - & 1 & 2 & 1 & 3 & 16 & 13 \\
\hline & $\begin{array}{c}\text { The settlement was refused } \\
\text { pursuant to art. } 183^{14} \S 3 \text { Code } \\
\text { of Civil Procedure }\end{array}$ & - & - & - & - & - & - & - & - \\
\hline \multirow{5}{*}{ 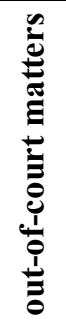 } & $\begin{array}{c}\text { Number of protocols submitted } \\
\text { by mediators (art. } 183^{13} \S 2 \text { Code } \\
\text { of Civil Procedure) }\end{array}$ & - & - & - & - & - & 1 & 2 & 2 \\
\hline & $\begin{array}{c}\text { Number of requests for } \\
\text { settlement approval }\end{array}$ & - & - & - & - & - & 1 & 2 & 2 \\
\hline & impact together & - & - & - & - & - & 2 & 4 & 4 \\
\hline & the settlement was approved & - & - & - & - & - & 1 & 2 & 2 \\
\hline & settlement approval refused & - & - & - & - & - & - & - & - \\
\hline
\end{tabular}

Source: own study based on data obtained from the analyzed Regional Court.

Based on the above table, it can be concluded that the number of cases referred to mediation is negligible. It is true that an upward trend can be observed especially in 2016, but already in 2017 the number of economic cases referred to mediation decreased. The number of out-ofcourt economic mediation is also small. In 2016 and 2017, only two applications were submitted for court approval of a mediation settlement.

The second District Court analyzed is characterized by the fact that each year it receives approximately 5,000 new lawsuits in economic cases. The number of economic cases pending before the court, compared to the previous District Court analyzed, is definitely higher. 


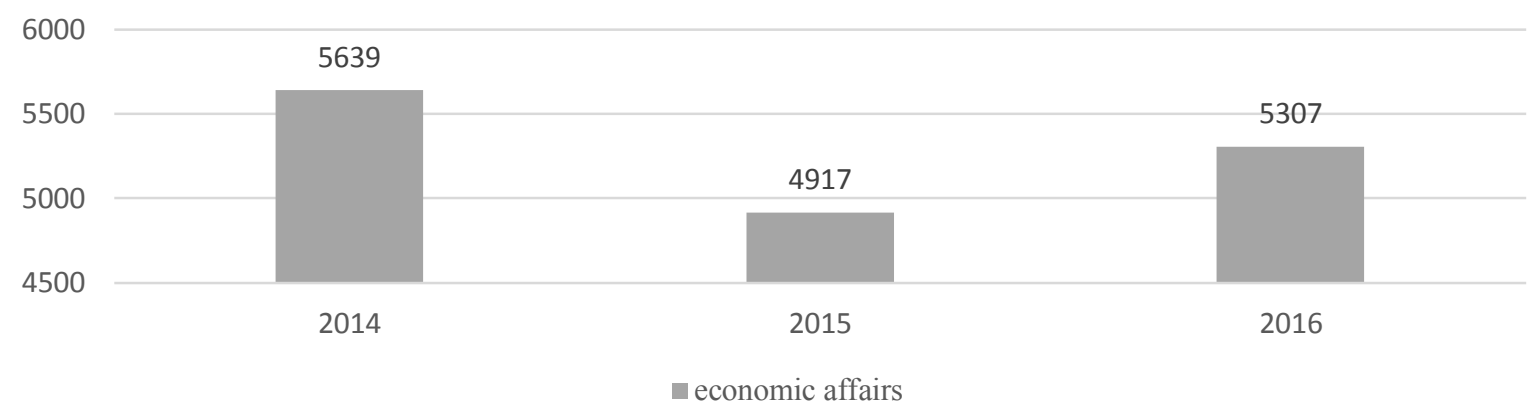

Figure 2. Incoming economic cases to the Regional Court in 2014-2016. Source: own study based on data from the Ministry of Justice.

In 2014, 5639 business cases were filed in the analyzed regional court, while in 2015 there was a slight decrease of approximately $12 \%$. In 2016, the number increased to 5307 cases. The table below presents the number of cases referred for mediation by the second analyzed district court in the Silesian Voivodeship.

Table 6.

Mediation proceedings in economic matters at the Regional Court in 2012-2017.

\begin{tabular}{|c|c|c|c|c|c|c|c|}
\hline \multicolumn{2}{|r|}{ Mediation matters } & 2012 & 2013 & 2014 & 2015 & 2016 & 2017 \\
\hline \multirow{5}{*}{$\stackrel{\infty}{=}$} & $\begin{array}{c}\text { Number of cases referred to mediation by a court } \\
\text { (art. } 183^{8} \S 1 \text { Code of Civil Procedure) }\end{array}$ & 63 & 42 & 39 & 42 & 26 & 20 \\
\hline & $\begin{array}{l}\text { Number of protocols submitted by mediators (art. } \\
183^{13} \S 2 \text { Code of Civil Procedure) }\end{array}$ & 27 & 56 & 24 & 45 & 17 & 11 \\
\hline & impact together & 90 & 98 & 63 & 87 & 43 & 31 \\
\hline & $\begin{array}{l}\text { approval of the settlement before the mediator } \\
\text { (art. } 183^{14} \S 1 \text { i } 2 \text { Code of Civil Procedure) }\end{array}$ & 11 & 3 & 11 & 4 & 1 & 11 \\
\hline & $\begin{array}{l}\text { The settlement was refused pursuant to art. } 183^{14} \\
\$ 3 \text { Code of Civil Procedure }\end{array}$ & - & - & - & - & - & - \\
\hline
\end{tabular}

Source: own study based on data obtained from the analyzed Regional Court.

Based on the above table, it can be concluded that the number of cases referred to mediation over the period 2012-2017 decreased by 30\%. In 2012, the court referred 63 business cases to mediation and approved the settlement in 11 cases, while in 2017 the court referred only 20 cases to mediation and approved the settlement in 11 cases. Unfortunately, no data was obtained from the court regarding the number of settlements obtained by out-of-court mediation.

Based on the above analysis, it can be concluded that in the Śląskie Voivodeship the number of cases referred to mediation is still small compared to the number of filed suits. Although mediation in the first court examined in recent years has an upward tendency, their number is still low. In turn, in the second analyzed court, the number of filed claims is twice as high (2016), however, the number of cases referred to mediation is definitely lower. Such a situation may be caused by the reluctance of entrepreneurs or the judiciary to mediation institutions, or little knowledge of it by the conflicting parties. 


\section{Summary}

Over the years, mediation has become more and more widespread and used on various levels of Polish law. Both in family, criminal, administrative, civil and business law, a mediation tool was used to provide the parties with the highest level of comfort on the way to assert their mutual claims. Currently, an increasing number of commercial cases pending before the courts can be observed, however, the institution of mediation still plays a negligible role in their resolution. The largest number of cases referred to mediation can be observed in the Mazowieckie voivodship, which can be safely called the mediation leader, while in the Śląskie Voivodeship the number of cases referred to mediation is still small. The parties' decision on the way to court proceedings may result from ignorance of the essence of mediation, but may also be associated with an incorrect interpretation of its rules of conduct, which may discourage the choice of this alternative method of dispute resolution. Mediation focuses on the future of the parties, avoids escalation of the problem and is a highly individualized process, but it is not free from defects. In order for the parties to reach an agreement, they must have similar expectations as to the effect of mediation, which is often impossible in the case of complex disputes. An undoubted problem regarding mediation is also the lack of trust of both courts and the public in this form of resolving the conflict. Currently, mediation is not sufficiently used, which is why education and promotion are so important in this regard. After proper popularization and overcoming society's reluctance, mediation should permanently appear in the Polish justice system. To achieve this, it is necessary to promote information on mediation, train judges in effective urging the parties to mediate, and make young people aware of the many benefits of settling everyday problems.

\section{References}

1. Article 2 (1), Act of 24 May 1989 on the recognition of commercial cases by courts (Journal of Laws 2016 item 723).

2. Directive 2008/52/EC of the European Parliament and of the Council of 21 May 2008 on certain aspects of mediation in civil and commercial matters (Official Journal EU L of 24 May 2008).

3. Doyle, A.W. (2016). Eurocontrol Agency Mediator \& Ethics Officer. Presentation at the Fourth National Corporate Mediation Conference in Amsterdam, the Netherlands on 24 May 2016.

4. Folberg, J., Taylor, A. (1984). Mediation. A Comprehensive Guide to Resolving Conflicts Without Litigation. San Francisco, p. 31. 
5. Gilovich, T., Ross, L. (2016). The Wisest One in the Room, How to Harness Psychology's Most Powerful Insights. London: Oneworld Publications, pp. 138-139.

6. Gójska, A., Huryn, V. (2007). Mediation in solving family conflicts. Warszawa: C.H. Beck, p. 41.

7. http://dlibra.bg.ajd.czest.pl:8080/Content/1549/Gubernaculum_02_6-9.pdf, 20.06.2018.

8. https://encyklopedia.pwn.pl/haslo/sprawiedliwosc-spoleczna;3978499.html, 27.01.2020.

9. Kalisz, A., Zienkiewicz, A. (2014). Mediacja sadowa i pozasqdowa. Zarys wykładu. Warszawa: Oficyna a Wolters Kluwer business, p. 43.

10. Kopaliński, W. (2000). Dictionary of foreign words and phrases with almanac. Warszawa, p. 321.

11. Lipsky, D., Seeber, R., Hall, L. (eds.) (2004). An Uncertain Destination: the development of conflict management systems in U.S. corporations. Alternative Dispute Resolution in the Employment Arena-Estreicher \& Sherwyn. The Hague, Kluwer Law International.

12. Mediation proceedings in the light of statistical data district and district courts in the years 2006-2018 and in the first half of 2019 (2019). Warszawa: the Ministry of Justice, p. 13.

13. Moll, T. (2015). Postępowanie mediacyjne na gruncie ustawy - Prawo o postępowaniu przed sądami administracyjnymi. Kwartalnik $A D R$, Nr 2(30), p. 39.

14. Nolan-Haley, J., Kwasi Annor-Ohene, J. (2014). Procedural Justice Beyond Borders: Mediation in Ghana. Harvard Negotiation Law Review Online, p. 5.

15. Penc, J. (1997). Business lexicon. Warszawa: Placet, pp. 23-24.

16. Peters, D. (2015). Introduction to the principles and theory of mediation. In: S. Pieckowski (ed.), Economic Mediation. Warszawa: Difin, pp. 27-28.

17. Pieckowski, S. (2015). Economic mediation. Warszawa: Difin, p. 10.

18. Rękas, A. (2011). Mediation in Polish criminal law. Warszawa: Ministry of Justice, p. 4.

19. Tabernacka, M. (2018). Negotiations and mediations in the public sphere. Warszawa: Wolters Kluwer, pp. 29-30.

20. The Act of 15 September 2000 Code of Commercial Companies, i.e. OJ 2017, item 1577. 